\title{
Pengembangan video bimbingan nuansa kalindaqdaq untuk meningkatkan konsep diri siswa MTs
}

\author{
Zulfianah Sunusi \\ Program Studi Bimbingan Konseling, Program Pascasarjana UNM \\ Email :Uppy_sun@yahoo.com
}

(Diterima: 02-Mei-2016; direvisi: 12-Juni-2016; dipublikasikan: 28-Juni-2016)

\begin{abstract}
The research is analyzing the video development of counseling using Kalindaqdaq nuance to improve the self concept of the students in MTs DDI Kec. Campalagian Kab. Polman. The research problem consists of (1) What is the descriptions of the self concept of the students in MTs DDI Kec. Campalagian Kab. Polman? (2) How to produce video of counseling with Kalindaqdaq nuance that is acceptable (utility, feasibility, and accuracy)? (3) Does the video of counseling using Kalindaqdaq nuance give effect/influrnce $t \mathrm{o}$ increase the self concept of the students in MTs DDI Kec. Campalagian Kab. Polman? The objectives of the research are (1) to know the description of the self conceptthe students in MTs DDI Kec. Campalagian Kab. Polman. (2) To create a video of counseling with Kalindaqdaq nuance which is acceptable (utuluty, feasibiliy), AND accuratiom. (3) to know the effect of the video of Kalindaqdaq nuance to enhance the self-concept of the students in MTs DDI Kec. Campalagian Kab. Polman.
\end{abstract}

Keywords: Counseling video; kalindaqdaq; self-concept.

\begin{abstract}
Abstrak: Penelitian ini menelaah pengembangan video bimbingan nuansa kalindaqdaq untuk meningkatkan konsep diri siswa di MTs DDI Lapeo Kec. Campalagian Kab. Polman. Rumusan Masalah penelitian ini adalah (1) Bagaimana gambaran konsep diri siswa di MTs DDI Lapeo Kec. Campalagian Kab. Polman? (2) Bagaimana menghasilkan video bimbingan nuansa kalindaqdaq yang acceptable (utility/kegunaan, feasibility/kelayakan, dan accuracy/ketepatan)? (3) Apakah video bimbingan nuansa kalindaqdaq berpengaruh untuk meningkatkan konsep diri siswa di MTs DDI Lapeo Kec. Campalagian Kab. Polman? Dan tujuan penelitian ini adalah (1) Untuk mengetahui gambaran konsep diri siswa di MTs DDI Lapeo Kec. Campalagian Kab. Polman; (2) Untuk menghasilkan video bimbingan nuansa kalindaqdaq yang acceptable (utility/kegunaan, feasibility/kelayakan, dan accuracy/ketepatan); (3) Untuk mengetahui pengaruh video bimbingan nuansa kalindaqdaq dalam meningkatkan konsep diri siswa MTs DDI Lapeo Kec. Campalagian Kab. Polman.
\end{abstract}

Kata Kunci: Video bimbingan; kalindaqdaq; konsep diri.

Copyright (C) 2016 Universitas Negeri Makassar. This is an open access article under the CC BYNC-ND license (http://creativecommons.org/licenses/by-nc-nd/4.0/).

\section{PENDAHULUAN}

Transisi memasuki sekolah menengah dari sekolah dasar merupakan tahapan yang wajar dialami oleh setiap siswa. Namun dapat menimbulkan stress jika siswa menghadapi perubahan simultan baik di dalam dirinya, keluarganya, dan sekolah. Upaya mengejawantahkan karakter yang disebutkan dalam tujuan pendidikan nasional tersebut tentunya bermula dari penataan konsep diri siswa itu sendiri. Konsep diri adalah aspek yang penting dari fungsi-fungsi manusia karena sebenarnya manusia sangat memperhatikan hal- 
hal yang berhubungan dengan dirinya, termasuk siapakah dirinya, seberapa baik mereka merasa tentang dirinya, seberapa efektif fungsi-fungsi mereka atau seberapa besar impresi yang mereka buat terhadap orang lain.

Namun pada kenyataannya pemberitaan yang muncul di koran, majalah, siaran berita televisi, maupun media massa berbasis internet tidak sejalan dengan harapan dunia pendidikan.

Berdasarkan hasil studi pendahuluan melalui angket konsep diri ditemukan siswa yang memiliki konsep diri tinggi hanya mencapai 35\% sedangkan siswa yang memiliki konsep diri rendah $65 \%$. Hal ini disebabkan oleh berbagai macam faktor seperti mendapat nama julukan karena terlalu gemuk, terlalu kurus, meniru artis idola, tuntutan teman-teman untuk selalu mengikuti trend berpakaian dan gaya hidup berkelimpahan materi serta keterlambatan kematangan.

Kecenderungan siswa meniru perilaku orang lain yang menarik baginya memberi andil terhadap peningkatan konsep diri siswa. Semakin mirip perilaku yang ditampakkannya dengan perilaku orang lain yang ingin ditirunya maka semakin meningkat konsep dirinya. Siswa belajar melalui hal-hal yang ada dilingkungannya.

Pada saat yang bersamaan acara-acara kebudayaan Mandar menjadi tontonan menarik bagi masyarakat setempat dari berbagai kalangan usia. Upacara Khataman Quran secara massal yang diadakan pada Hari Raya Maulid menampilkan arak-arakan kuda penari yang ditunggangi oleh anak-anak yang baru saja menamatkan Al-Quran. Segala komponen upacara kebudayaan baik berupa iringan musik rebana, pakaian adat, kecakapan kuda, keindahan syair dan irama kalindaqdaq, gaya puitis dan jenaka pakkalindaqdaq hingga sorak sorai penonton memberi kesan yang tertanam kuat dalam ingatan penontonnya.

Salah satu komponen upacara kebudayan tersebut adalah kalindaqdaq. Kalindaqdaq ialah karya sastra puisi berbahasa Mandar yang diikat oleh syarat-syarat tertentu yang harus dipenuhi, seperti jumlah larik (baris) kalimat dalam tiap bait, jumlah suku kata dalam tiap baris, dan irama yang tetap (Yasil, 2013:'5). Pada larik pertama terdiri atas 8 suku kata, larik ke dua 7 suku kata. Larik ketiga 5 suku kata saja sedangkan larik terakhir atau keempat kembali pada 7 suku kata. Pola tetap 8757 inilah ketika dibacakan juga membentuk nada tetap meskipun pada syair kalindaqdaq yang berbeda. Uru-uru uitammu (8 suku kata) tappa mongeq mating (7 suku kata) tappa andiang (5 suku kata) tambar paulianna (7 suku kata). Arti syair tersebut: Sejak pertama melihatmu, seketika itu hatiku terpaut padamu, seketika itu tiada, penawar pengobatnya.

Secara khusus daya tarik sajian budaya kalindaqdaq terletak pada kesyahduan irama yang dihasilkan oleh pola suku kata, keindahan makna syair yang dikandungnya dan gestur dari pelantun kalindaqdaq itu sendiri. Lirik, pola irama yang tetap dan gestur pelantun kalindaqdaq secara utuh menggambarkan seberapa baik seseorang merasa tentang dirinya. Semakin baik seseorang dalam melantunkan kalindaqdaq, maka ia merasa dirinya semakin baik.

Siswa memberi atensi yang lebih besar terhadap pelantun kalindaqdaq yang sebaya dengannya. Pelantun kalindaqdaq muda dianggap lebih menarik, percaya diri, dan berkesan dalam benak siswa. Oleh karena itu digunakan video untuk merekam momen penting ketika pelantun kalindaqdaq yang sebaya dengan siswa melakukan aksinya pada upacara khataman. Sebagaimana peran media menurut Djamarah (2010: 120) bahwa media dapat mewakili apa yang kurang mampu guru ucapkan melalui kata-kata atau kalimat tertentu. Hasil penelitian menjelaskan bahwa penggunaan video sebagai media bimbingan konseling sangat besar keberterimaan dan kegunaan dalam mengatasi permasalahan anak diantaranya keterampilan sosial. (Bakhtiar, 2015)

Berdasarkan uraian analisis kebutuhan tersebut di atas, maka peneliti melakukan penelitian yang berkaitan dengan pengembangan modeling simbolis untuk meningkatkan konsep diri siswa, sehingga judul penelitian yang akan dikembangkan yakni "Pengembangan video bimbingan konseling bernuansa kalindaqdaq untuk meningkatkan konsep diri siswa MTs DDI Campalagian".

Berdasarkan dari rumusan masalah di atas, maka yang menjadi tujuan penelitian ini yaitu: (1) Mengetahui gambaran konsep diri siswa di MTs DDI Campalagian; (2) Menghasilkan suatu video bimbingan nuansa kalindaqdaq yang acceptable untuk meningkatkan konsep diri siswa; (3) Mengetahui pengaruh video bimbingan nuansa kalindaqdaq dalam meningkatkan konsep diri siswa. 


\section{METODE}

Dalam penelitian ini dilakukan dengan menggunakan pendekatan "Penelitian Pengembangan" (Research and Development).

Menurut Borg and Gall (2003,782, Farida, 2014) strategi research and development (R\&D) ini merupakan siklus pengembangan yang terdiri dari 9 langkah pengembangan yaitu : (1) analisis kebutuhan; (2) penelitian awal \& pengumpulan informasi; (3) perencanaan pengembangan; (4) pengembangan produk awal; (5) uji lapangan awal (validasi ahli); (6) revisi I; (7) uji kelompok kecil; (8) revisi II; (9) uji kelompok besar; dan (10) deseminasi \& implementasi.

Penelitian pengembangan ini dilakukan pada siswa MTs DDI Kecamatan Campalagian Kabupaten Polewali Mandar.

Pada tahap uji ahli atau validasi ahli ini peneliti mengujikan produk video $\mathrm{BnK}$ kepada tiga ahli; ahli bimbingan dan konseling, ahli media pendidikan dan ahli praktisi bimbingan dan konseling yang didatangkan dari SMP Negeri 4 Polewali berhubung guru pembimbing pada tempat penelitian belum ada yang mencapai 10 tahun masa pengabdian.

Teknik Pemilihan Sampel

Peneliti akan menggunakan teknik pemilihan sampel dengan cara purposive sampling atau sampel bertujuan.

Jenis data

Data yang diperoleh dalam pengembangan video BnK untuk meningkatkan konsep diri siswa berupa data kualitatif dan kuantitatif.

Instrumen Pengumpulan Data: a) Skala, Skala konsep diri disusun oleh peneliti berdasarkan aspek-aspek yang menjadi ciri konsep diri positif (Calhoun \& Acocella dalam Killing: 2015) dengan tiga karakteristik konsep diri positif yakni keterbukaan diri, kepercayaan diri, dan optimisme. Bentuk skala yang digunakan oleh peneliti adalah bentuk skala Likert.

Teknik Analisis Data

Teknik analisis data yang digunakan untuk mengolah data yang diperoleh dalam pengembangan program ini adalah dengan menggunakan analisis isi, analisis deskriptif dan t- test.

\section{HASIL DAN PEMBAHASAN}

Adapun materi yang diberikan pada tahap kegiatan ini meliputi penayangn seseorang yang melantunkan kalindaqdaq dengan konsep diri positif, ilustrasi konsep diri negatif dan konsep diri positif .

Materi yang diprogramkan.

1) Tenaga yang dipersiapkan.

Penelitian ini dilakukan langsung oleh peneliti yaitu sebagai fasilitator dan didampingi oleh seorang wali kelas, dan seorang teman peneliti yang membantu mempersiapkan sarana dan prasarana yang akan digunakan.

2) Prosedur pelaksanaan.

Pelaksanaan kegiatan Video BnK yang dikembangkan oleh peneliti dilakukan secara berkolaborasi melalui empat tahap yaitu tahap persiapan yang meliputi membangun rapport dan menjelaskan tujuan kegiatan; tahap penyampaian yang meliputi penjelasan materi; tanya jawab, dan pemutaran video; tahap kegiatan pelatihan yang meliputi mencontoh model dalam video dengan melantunkan kalindaqdaq, dan tahap evaluasi atau penutup. Dalam proses pelaksanaan kegiatan model yang dikembangkan, peneliti mengacu pada tiga keterampilan yang telah ditentukan secara terstruktur yang disesuaikan dengan materi video terhadap siswa yang memiliki konsep diri rendah (negatif) sehingga dapat meningkatkan konsep dirinya. Adapun tahap kegiatan yang dilakukan meliputi: keterbukaan diri, kepercayaan diri, dan keyakinan diri.

3) Sarana-prasarana yang diperlukan untuk kegiatan yaitu : LCD, Laptop, Pengeras suara (Speaker), Materi dalam bentuk Video BnK, dan Alat tulis menulis

Hasil Uji Validasi Ahli. Pada tahap ini peneliti mengajukan video Bimbingan nuansa Kalindaqdaq (BnK) yang akan dikembangkan menjadi dua tahap yaitu tahap validasi video BnK oleh ahli media pendidikan dan kemudian dilakukan uji akseptabilitas yang mencakup: uji kegunaan, uji kelayakan, serta uji ketepatan pada video $\mathrm{BnK}$ tersebut oleh tiga ahli. 
Sunusi. Pengembangan video bimbingan... | 36

\section{Hasil Data Angket Penilaian Akseptabilitas}

Tabel 4.1 Hasil Penilaian Uji Kegunaan (Utility) Video BnK oleh Ahli 1, 2 dan 3

\begin{tabular}{cccrcc}
\hline \multirow{2}{*}{$\begin{array}{c}\text { Pernyata } \\
\text { an }\end{array}$} & \multicolumn{3}{c}{ Tingkat Kegunaan } & Jumlah & $\%$ \\
\hline & Ahli 1 & Ahli 2 & Ahli 3 & & \\
\hline 1 & 3 & 3 & 3 & 9 & 75 \\
\hline 2 & 3 & 4 & 3 & 10 & 83,3 \\
\hline 3 & 3 & 3 & 3 & 9 & 75 \\
\hline 4 & 3 & 4 & 3 & 10 & 83,3 \\
\hline 5 & 3 & 3 & 3 & 9 & 75 \\
\hline 6 & 3 & 4 & 4 & 11 & 91,6 \\
\hline 7 & 3 & 4 & 4 & 11 & 91,6 \\
\hline Jumlah & 21 & 25 & 23 & 69 & \\
\hline$\%$ & 84 & 98,22 & 92 & & 93,24 \\
\hline
\end{tabular}

Rata-rata nilai dari hasil uji kegunaan diperoleh nilai sebesar 93,24\%, sehingga dari data ini diketahui bahwa video
Bimbingan nuansa Kalindaqdaq yang dirancang oleh peneliti dinilai berguna (utility) untuk digunakan oleh guru pembimbing di sekolah dalam meningkatkan konsep diri siswa.

Tabel 4.2 Hasil Penilaian Uji Kelayakan (feasibility) Video BnK oleh Ahli

\begin{tabular}{cccccc}
\hline Pernyataan & \multicolumn{3}{c}{ Tingkat Kegunaan } & \multirow{2}{*}{ Jumlah } & \multirow{2}{*}{$\%$} \\
\cline { 2 - 4 } & Ahli 1 & Ahli 2 & Ahli 3 & & 75 \\
\hline 1 & 3 & 3 & 3 & 9 & 91,6 \\
\hline 2 & 3 & 4 & 4 & 11 & 91,6 \\
\hline 3 & 3 & 4 & 4 & 11 & 91,6 \\
\hline 4 & 3 & 4 & 4 & 11 & 75 \\
\hline 5 & 3 & 3 & 3 & 9 & 91,6 \\
\hline 6 & 3 & 4 & 4 & 11 & 86,11 \\
\hline Jumlah & 18 & 16 & 16 & 62 & \\
\hline$\%$ & 75 & 66,66 & 66,66 & &
\end{tabular}

Rata-rata nilai dari hasil uji kegunaan diperoleh nilai sebesar $86,11 \%$ sehingga dari data ini diketahui bahwa video Bimbingan nuansa Kalindaqdaq memiliki tingkat kelayakan (feasibility) yang besar bagi pembimbing maupun siswa di sekolah.

Tabel 4.3 Hasil Penilaian Uji Ketepatan (Accuracy)Video BnK oleh Ahli

\begin{tabular}{cccccc}
\hline Pernyataan & \multicolumn{3}{c}{ Tingkat Kegunaan } & Jumlah & $\%$ \\
\cline { 2 - 4 } & Ahli 1 & Ahli 2 & Ahli 3 & & \\
\hline 1 & 3 & 4 & 4 & 11 & 91,6 \\
\hline 2 & 3 & 3 & 3 & 9 & 75 \\
\hline 3 & 3 & 3 & 3 & 9 & 75 \\
\hline 4 & 3 & 3 & 3 & 9 & 75 \\
\hline 5 & 3 & 4 & 4 & 11 & 91,6 \\
\hline 6 & 3 & 4 & 4 & 11 & 91,6 \\
\hline Jumlah & 18 & 21 & 21 & 60 & \\
\hline$\%$ & 75 & 87,5 & 87,5 & & 83,33 \\
\hline
\end{tabular}


Rata-rata nilai dari hasil uji kegunaan diperoleh nilai sebesar $83,33 \%$ sehingga dari data ini diketahui bahwa video Bimbingan nuansa Kalindaqdaq memiliki tingkat ketepatan (accuracy) yang besar bagi guru pembimbing maupun siswa di sekolah.

Revisi I. Adapun revisi yang dilakukan adalah revisi terhadap video BnK dalam meningkatkan konsep diri siswa yang sedang dikembangkan.

Uji Coba Produk (Uji Coba Kelompok Kecil). Pada tahap ini, peneliti melakukan uji coba kelompok kecil. Uji coba kelompok kecil bertujuan untuk mengetahui kelayakan atau keberterimaan video Bimbingan nuansa Kalindaqdaq yang dikembangkan dan hal apa saja yang perlu direvisi sebelum melakukan uji efektivitas (uji kelompok besar). Uji kelompok kecil melibatkan 8 siswa kelas VII. Berikut hasil penilaian lembar evaluasi kegiatan diskusi kelompok mulai sesi I (pertama) sampai pada sesi III (tiga) dalam meningkatkan konsep diri siswa. Siswa diberikan perlakuan berupa diskusi kelompok menggunakan media modeling simbolis berupa video bimbingan nuansa kalindaqdaq dan penilaian umum berupa pengisian lembar evaluasi dalam setiap pertemuan untuk mengetahui pemahaman siswa terhadap konsep diri melalui penggunaan video bimbingan nuansa kalindaqdaq.

Penilaian yang diberikan kepada siswa pada setiap sesi pelaksanaan kegiatan dengan mengisi lembar evaluasi, diberikan penilaian Kurang jika siswa belum mampu mengisi dan menjelaskan lembar evaluasi yang diberikan. Kemudian penilaian Cukup jika siswa mampu melengkapi lembar evaluasi yang diberikan namun masih ada item pada lembar evaluasi yang belum lengkap, untuk penilaian Baik akan diberikan kepada siswa jika mampu mengisi lembar evaluasi yang diberikan sesuai dengan tujuan yang ingin dicapai.

Tabel 4.4 Hasil penilaian lembar evaluasi video BnK pada tahap pertama

\begin{tabular}{|c|c|c|}
\hline \multirow[t]{2}{*}{ Nama Responden } & \multicolumn{2}{|l|}{ Hasil Penilaian } \\
\hline & Cukup & Baik \\
\hline IR & $\sqrt{ }$ & \\
\hline HK & $\sqrt{ }$ & \\
\hline $\mathrm{RR}$ & $\sqrt{ }$ & \\
\hline IS & & $\sqrt{ }$ \\
\hline ML & & $\sqrt{ }$ \\
\hline MR & & $\sqrt{ }$ \\
\hline $\mathrm{MN}$ & & $\sqrt{ }$ \\
\hline RM & & $\sqrt{ }$ \\
\hline Jumlah Responden & $\sum 37,5 \%$ & $\sum 62,5 \%$ \\
\hline
\end{tabular}

Sumber: Hasil lembar evaluasi siswa

Secara umum hasilnya menunjukkan bahwa siswa mampu menyelesaikan lembar evaluasi yang diberikan dengan baik berdasarkan tujuan yang diharapkan, yaitu dari delapan siswa yang melakukan kegiatan diskusi kelompok melalui video Bimbingan nuansa Kalindaqdaq, sebanyak 5 orang $(62,5 \%)$ yang mampu mengisi lembar evaluasi dengan baik, sementara siswa yang berada pada kategori cukup sebanyak 3 siswa $(37,5 \%)$.

Tabel 4.5 Hasil penilaian lembar evaluasi video BnK pada tahap kedua

\begin{tabular}{lccc}
\hline \multirow{2}{*}{ Nama Responden } & Hasil Penilaian & \\
\cline { 2 - 3 } & Kurang & Cukup & Baik \\
\hline IR & $\sqrt{ }$ & $\sqrt{ }$ \\
\hline HK & & $\sqrt{ }$ \\
\hline RR & & $\sqrt{ }$ \\
\hline IS & & & \multicolumn{1}{l}{} \\
\hline
\end{tabular}




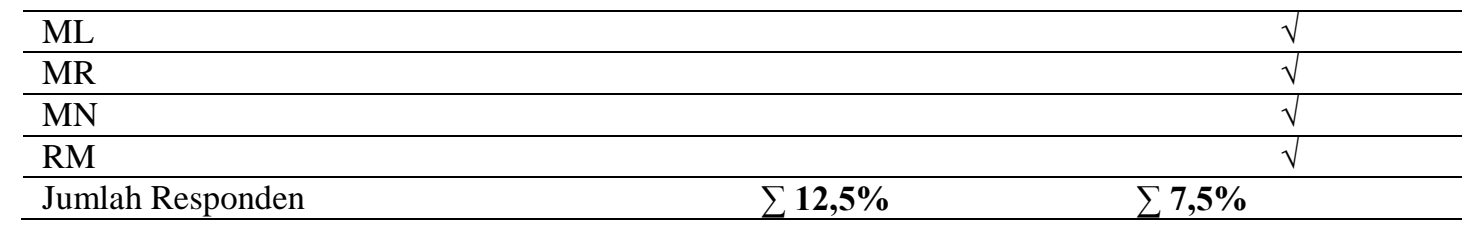

Tabel 4.6 di atas, menunjukkan bahwa sebagian besar yaitu 7 siswa $(87,5 \%)$ mampu memahami video Bimbingan nuansa Kalindaqdaq ilustrasi "Si Acang_episode pertama" yang bertujuan untuk membantu siswa mengetahi pengaruh pelabelan (stereotype) terhadap terbentuknya konsep diri negatif

Tabel 4.6 Hasil penilaian lembar evaluasi video BnK pada tahap ketiga

\begin{tabular}{|c|c|c|c|}
\hline \multirow{2}{*}{ Nama Responden } & \multicolumn{3}{|c|}{ Hasil Penilaian } \\
\hline & Kurang & Cukup & Baik \\
\hline IR & & & $\sqrt{ }$ \\
\hline HK & & & $\sqrt{ }$ \\
\hline RR & & & $\sqrt{ }$ \\
\hline IS & & & $\sqrt{ }$ \\
\hline ML & & & $\sqrt{ }$ \\
\hline MR & & & $\sqrt{ }$ \\
\hline $\mathrm{MN}$ & & $\sqrt{ }$ & \\
\hline RM & & & $\sqrt{ }$ \\
\hline Jumlah Responden & & & $\sqrt{ }$ \\
\hline
\end{tabular}

Sumber: Hasil lembar evaluasi siswa

Tahap kegiatan ketiga bertujuan untuk membantu siswa memahami pengaruh kalimat positif terhadap pembentukan konsep diri.

Tingkat skala penilaian yang diberikan kepada delapan siswa secara keseluruhan dari tiga sesi pertemuan menunjukkan bahwa rata-rata tingkat kemampuan siswa dalam mengerjakan lembar evaluasi konsep diri berada pada kategori

baik. Berdasarkan uraian penilaian dari siswa yang mengikuti kegiatan diskusi kelompok menggunakan video $\mathrm{BnK}$ di atas, dapat dikatakan bahwa video BnK layak digunakan dan diterima sebagai video bimbingan untuk membantu siswa meningkatkan konsep dirinya.

Hasil analisis data konsep diri siswa sebelum dan sesudah pemberian video BnK dapat dilihat sebagai berikut:

Tabel 4.7 Data Konsep Diri Siswa Sebelum dan Setelah Pemberian Video BnK

\begin{tabular}{llcccc}
\hline \multirow{2}{*}{ Interval } & \multicolumn{1}{c}{$\begin{array}{c}\text { Konsep diri } \\
\text { Siswa }\end{array}$} & \multicolumn{4}{c}{ Kelompok Eksperimen } \\
\cline { 3 - 6 } & & & Sebelum kegiatan & \multicolumn{2}{c}{ Sesudah kegiatan } \\
\cline { 3 - 6 } & & $\mathbf{F}$ & $\begin{array}{c}\mathbf{P} \\
(\boldsymbol{\%})\end{array}$ & $\mathbf{F}$ & $\begin{array}{c}\mathbf{P} \\
(\boldsymbol{\%})\end{array}$ \\
\hline $168-200$ & Sangat Tinggi & - & - & 4 & 10 \\
\hline $136-167$ & Tinggi & - & - & 8 & 20 \\
\hline $104-135$ & Sedang & 11 & 27,5 & 26 & 65 \\
\hline $72-103$ & Rendah & 22 & 55 & 2 & 5 \\
\hline $40-71$ & Sangat Rendah & 7 & 17,5 & - & - \\
\hline & Jumlah & $\mathbf{4 0}$ & $\mathbf{1 0 0}$ & $\mathbf{4 0}$ & $\mathbf{1 0 0}$
\end{tabular}

Sumber: Hasil angket eksperimen 
Berdasarkan data di atas, dapat disimpulkan bahwa konsep diri siswa sebelum mendapat video Bimbingan nuansa Kalindaqdaq dominan berada pada kategori rendah yaitu sebanyak 22 responden (55\%). Setelah mengikuti kegiatan diskusi kelompok teknik modeling simbolik menggunakan video Bimbingan nuansa Kalindaqdaq yang dilakukan selama tujuh sesi kegiatan menunjukkan bahwa konsep diri siswa mengalami peningkatan atau perubahan secara signifikan yaitu dominan siswa berada pada ketegori sedang sebanyak 26 responden $(65 \%)$ dan kategori tinggi dan sangat tinggi masingmasing sebanyak 8 responden $(20 \%)$ dan 4 responden $(10 \%)$.

Tabel 4.8 Data Konsep Diri Siswa Sebelum dan Sesudah diberikan Video BnK

\begin{tabular}{llllll}
\hline Data & N & MEAN & SD & t & Sig \\
\hline Sebelum kegiatan & 40 & 97,2 & 39 & & \\
Sesudah kegiatan & 40 & 131,5 & 39 & 19,33 & 0,000 \\
\hline
\end{tabular}

Sumber: Hasil Gain Skor

Berdasarkan hasil penghitungan dengan menggunakan SPSS 16 for windows melalui paired sample t-test terdapat perbedaan nilai rata-rata setelah perlakuan lebih tinggi dari sebelum diberikan perlakuan Video BnK, dengan nilai $\mathrm{t}=19,33$ dengan $\mathrm{df}=39$ Harga $\mathrm{t}_{\text {tabel }}$ pada $\mathrm{t}$ $0,05=2,02$ dengan nilai signifikan $(\mathrm{P})=0,000<$ $\alpha=0,05$. Hal ini berarti bahwa hipotesis nihil $\left(\mathrm{H}_{0}\right)$ yang berbunyi "Tidak ada pengaruh positif terhadap konsep diri siswa setelah kegiatan diskusi kelompok dengan teknik modeling simbolis melalui penggunaan video Bimbingan nuansa Kalindaqdaq diterapkan di MTs DDI Lapeo Kec.Campalagian" dinyatakan ditolak. Sehingga hipotesis kerja $\left(\mathrm{H}_{1}\right)$ yaitu "Ada pengaruh positif terhadap peningkatan konsep diri siswa setelah penggunaan video Bimbingan nuansa Kalindaqdaq di MTs DDI Lapeo Kec. Campalagian" dinyatakan diterima. Berdasarkan hasil pengujian kelompok besar dengan melibatkan sebanyak 40 siswa pada tabel di atas terlihat rata-rata untuk sebelum layanan adalah 97,2 dan setelah layanan adalah 131,5 artinya rata-rata sebelum layanan lebih rendah daripada rata-rata setelah pemberian kegiatan video Bimbingan nuansa Kalindaqdaq. Dengan ini, maka dapat disimpulkan bahwa dengan adanya penerapan video Bimbingan nuansa Kalindaqdaq dapat meningkatkan konsep diri siswa di MTs DDI Lapeo Kec.Campalagian.

Setelah melaksanakan tahapan-tahapan penelitian di atas, maka lahirlah video Bimbingan nuansa Kalindaqdaq yang telah diuji oleh ahli, baik melalui uji kelompok kecil maupun uji kelompok besar (uji efektivitas) yang terbukti memberikan perubahan secara signifikan yaitu dapat meningkatkan konsep diri siswa di
MTs DDI Lapeo Kec. Campalagian.

Tujuan penelitian ini adalah untuk mengetahui gambaran konsep diri siswa di MTs DDI Lapeo Kec. Campalagian, untuk menghasilkan video Bimbingan nuansa Kalindaqdaq yang dapat meningkatkan konsep diri siswa, dan untuk mengetahui apakah video Bimbingan nuansa Kalindaqdaq yang dihasilkan dapat meningkatkan konsep diri siswa di MTs DDI Lapeo Kec. Campalagian.

Adapun yang menyebabkan terjadinya peningkatan konsep diri siswa di MTs DDI Lapeo Kec. Campalagian setelah penayangan Video BnK dalam rangkaian kegiatan bimbingan disebabkan karena adanya muatan-muatan positif yang terkandung di dalam video Bimbingan nuansa Kalindaqdaq yang telah dikembangkan berupa penayangan video Bimbingan nuansa Kalindaqdaq yang menarik karena disertai suara musik rebana khas mandar yang mengiringi pelantun syair Kalindaqdaq. Kedua, pemberian ilustrasi cerita yang berhubungan langsung dengan kondisi siswa yang mengalami masalahmasalah konsep diri sehingga mudah dipahami dan dimengerti oleh siswa yang bersangkutan. Ketiga, pada video BnK yang dikembangkan memuat syair yang memiliki makna pantang menyerah sekaligus sebagai ciri khas pembeda dengan video bimbingan pada umumnya. Keempat, pelaksanaan kegiatan video Bimbingan nuansa Kalindaqdaq yang telah dikembangkan oleh peneliti lebih menarik karena dalam proses pelaksanaannya selalu disertai dengan modeling simbolik yang bertujuan melatih siswa meniru perilaku dalam tayangan video dan memberi pengalaman baru bagi siswa dalam proses meningkatkan konsep dirinya. 
Penelitian terkait yang dilakukan oleh Iskandar, dkk (2014) yang menyatakan bahwa, "penggunaan modeling media video dapat meningkatkan kemampuan cuci tangan pada siswa kelas 4 di SD Wonosari Wangkang Semarang". Demikian pula dengan hasil penelitian Megawati (2011) bahwa subyek mengalami peningkatan pada keterampilan toilet training setelah diberikan intervensi tayangan modeling melalui media video. Dengan demikian, dapat disimpulkan bahwa tayangan melalui media video dapat menjadi modeling yang baik untuk menciptakan suatu pemahaman dan perilaku baru.

\section{SIMPULAN DAN SARAN}

Berdasarkan analisis data dan pembahasan hasil penelitian, maka dapat disimpulkan bahwa: 1) Konsep diri siswa di MTs DDI Lapeo Kec. Campalagian sangat rendah. Masih banyak ditemui siswa dengan keterbukaan diri yang rendah, kurangnya kepercayaan diri dan optimisme untuk memperbaiki diri sangat kurang; 2) Video Bimbingan nuansa Kalindaqdaq yang dapat meningkatkan konsep diri siswa yang valid, praktis, dan menarik dikembangkan menjadi tiga bagian penayangan. Bagian pertama menampilkan perkenalan materi konsep diri kemudian bagian kedua menampilkan ilustrasi siswa dengan konsep diri negatif dan ilustrasi terakhir menampilkan siswa dengan konsep diri positif; 3) Penggunaaan video Bimbingan nuansa Kalindaqdaq efektif dalam meningkatkan konsep diri siswa di kelas VII MTs DDI Lapeo Kec. Campalagian.

Sehubungan dengan kesimpulan penelitian di atas, maka diajukan saran-saran sebagai berikut: 1) Bagi stakeholder, adanya video BnK tersebut bukan berarti guru pembimbing mengabaikan program yang lain akan tetapi membantu guru pembimbing dalam menghasilkan program video lain seperti bimbingan belajar dan bimbingan karir yang secara khusus diperuntukkan sesuai kebutuhan siswa; 2) Bagi mahasiswa program studi bimbingan dan konseling, hasil penelitian pengembangan ini dapat dijadikan salah satu contoh dalam penyusunan pengembangan program bimbingan dan konseling yaitu program bimbingan pribadi-sosial. Selain itu perlu dilakukan penelitian yang lebih lanjut mengenai uji efektivitas ke sekolah-sekolah. 3) Bagi peneliti selanjutnya perlu mempertimbangkan beberapa hal dalam penelitian pengembangan video program bimbingan dan konseling khususnya pada program bimbingan pribadisosial antara lain; a) keterbatasan waktu pelaksananaan, b) keterbatasan media yang ada di sekolah, c) kesesuaian bahasa yang digunakan peserta didik, d) kesesuaian konteks skenario dengan kebiasaan sehari-hari siswa dan e) ketersediaan pemeran ahli.

\section{DAFTAR RUJUKAN}

Borg, W \& Gall, M. (2003). Education Research and Introduction. Fourth Edition. New York: Longman Inc

Bakhtiar, M. I. (2015). Pengembangan Video Ice Breaking Sebagai Media Bimbingan Konseling. Jurnal Psikologi Pendidikan Dan Konseling, 1(2), 150-163. http://ojs.unm.ac.id/index.php/JPPK/artic le/view/1816

Aryani, F. (2014). Model Character Development Training ( Cdt ) Untuk Meningkatkan Perilaku. Jurnal Pendidikan Dan Pengajaran, 47(1), 21-28.

Killing, B. N. 2015. Tinjauan Konsep Diri dan Dimensinya pada Anak dalam Masa KanakKanak Akhir. Jurnal Psikologi Pendidikan dan Konseling, 1 (2), 116-124. http://ojs.unm.ac.id/index.php/JPPK/article/ view/1811

Djamarah, S.B. (2010). Strategi Belajar Mengajar. Jakarta: PT.Rineka Cipta

Iskandar, Heru, Suhadi \& Maryati. (2014). Pengaruh Modeling Media Video Cuci Tangan Terhadap Kemampuan Cuci Tangan pada Siswa Kelas 4 di SD Wonosari 02 Mangkang Semarang. Skripsi. Tidak Diterbitkan. Semarang: STIKES.

Megawati, R.D. (2011). Modeling melalui media video sebagai teknik toiletTaraining siswa down syndrome. Tesis. Tidak Diterbitkan. Bandung: UPI.

Yasil, Suradi. (2013). Puisi Mandar Kalindaqdaq: dalam beberapa tema. Yogyakarta: Ombak. 